\title{
A negative binomial model for student allocation to higher education in Portugal during the Post-Bologna process
}

Cite as: AIP Conference Proceedings 1978, 470103 (2018); https://doi.org/10.1063/1.5044173 Published Online: 10 July 2018

Raquel Oliveira, A. Manuela Gonçalves, and Rosa M. Vasconcelos

ARTICLES YOU MAY BE INTERESTED IN

Time series analysis by state space models applied to a water quality data in Portugal AIP Conference Proceedings 1978, 470101 (2018); https://doi.org/10.1063/1.5044171

A statistical model for the demand of undergraduate engineering courses in Portugal: A first study of Bologna Process impact

AIP Conference Proceedings 1479, 1724 (2012); https://doi.org/10.1063/1.4756505

Challenge us.

What are your needs for periodic signal detection?

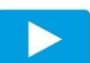

Watch

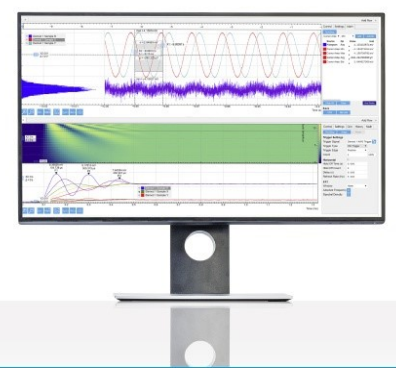

Zurich Instruments 


\title{
A Negative Binomial Model for Student Allocation to Higher Education in Portugal during the Post-Bologna Process
}

\author{
Raquel Oliveira ${ }^{1, \text { a) }}$, A. Manuela Gonçalves ${ }^{2, \text { b) }}$ and Rosa M. Vasconcelos ${ }^{3, c)}$ \\ ${ }^{I}$ CMAT-Centre of Mathematics, University of Minho, IPCA_EST, Barcelos, Portugal \\ ${ }^{2}$ CMAT-Centre of Mathematics, DMA-Department of Mathematics and Applications, University of Minho, \\ Portugal \\ ${ }^{3} 2 C 2 T$ - Centre for Textile Science and Technology, DET-Department of Textile Engineering, University of Minho, \\ Portugal \\ a)rmro_17@hotmail.com \\ b)mneves@math.uminho.pt \\ c)rosa@det.uminho.pt
}

\begin{abstract}
The primary goal of this paper is to model the student allocation in the Portuguese public higher education system, namely in academic engineering programs for the Post-Bologna period. This work follows the results obtained for the Pre-Bologna period. The data used refer to the years 2007 to 2015 and most of them are available online, provided by the Portuguese Ministry of Education. By estimating student allocation through the negative binomial regression model, we have concluded that the results are similar to the results already obtained for the Pre-Bologna period. That is, the model had a satisfactory performance for the data in study.
\end{abstract}

\section{INTRODUCTION}

It is well known that the implementation of the Bologna process has brought major changes in the organization of higher education, particularly regarding the students access.

The common duration of a higher academic program degree in the Pre-Bologna period used to be five years; in the mid-90s could also be of four years. The Bologna process imposes programs with the duration of three years. However, Portugal considers the possibility of maintaining a longer duration. Thus, after the implementation of the Bologna process, the available degrees have become:

- $\quad$ First cycle (licenciatura-L) - 3 years;

- Second cycle (mestrado) -1.5 to 2 years.

It is possible as well to offer a combined degree called integrated master (mestrado integrado-MI), with the duration of 5 or 6 years.

Note that, as described in [1], Portugal has a binary higher education system, consisting of university (U) and polytechnic institutes (PI). Only the universities may offer the integrated master degree. So, the national contest for access to higher education is done for the first cycles in universities and polytechnic institutes, and for integrated masters in universities. The access to the second cycle (mestrado) is of the responsibility of each institution of higher education (IHE). This study focused on the national competition results.

In this work we intend to analyze the behavior of the model applied in [1] for the Post-Bologna period (20072015), in order to confirm the results obtained for the Pre-Bologna period. 


\section{DATA ANALYSIS}

The data set used covers the years from 2007 to 2015, the so called Post-Bologna period. Almost all of the data is available online, on a website of the Department of Higher Education (Direção Geral do Ensino Superior-DGES) [2], dedicated to announce the results of the national contest for access to higher education.

Figure 1 represents the number of IHE, each year, for the national contest by the type of IHE and illustrates the total of allocated applicants in the Post-Bologna period.

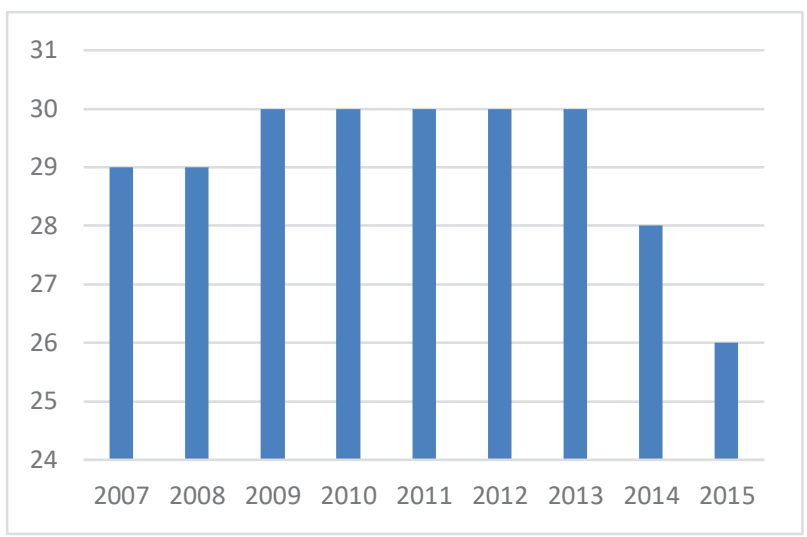

(a)

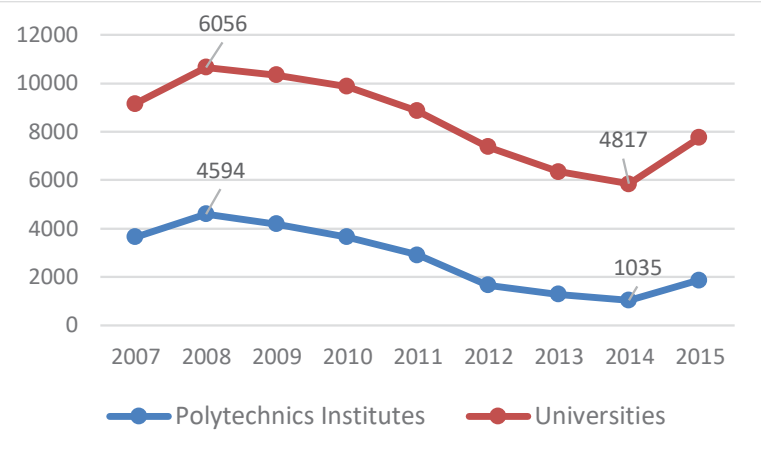

(b)

FIGURE 1. (a) Number of IHE and (b) Total of allocated applicants

As we can see from Fig. 1(a) the number of IHE varies between 26 and 30. In the last two years it was observed a sharp decrease in the number of IHE, reaching the minimum in 2015. In respect of the number of the allocated applicants, Fig. 1(b) shows that the number of students allocated reached the minimum values in the period 20122015, in both type of IHE, with an increase in 2015.

Table 1 shows the number of academic programs available, each year, for the national contest by the type of HEI.

As in [1], the variables considered are: number of allocated applicants in each program (total number of allocated students in the pair institution/program, irrespective of their ranking); number of vacancies available in each program in the first stage of the application process; classification of the last allocated student, academic program size: first cycle (licenciatura) and integrated master (mestrado integrado).

We present in Table 2 a brief of some variables available.

Figure 2 presents the minimum and maximum values of the classification of the last allocated student by type of IHE. Observing Fig. 2. we can conclude that the classification of the last allocated student is higher in the universities, both in its minimum or maximum values.

\section{RESULTS}

Similarly to [1], we want to explain the number of allocated applicants in each pair institution/program. Thus, we apply the model presented in [3], based on similar conditions to those applied in [4] and [5], considering the following explanatory variables: number of vacancies available in each program during the first phase, classification of the last placed applicant, type of institution and program size. As in [3], we applied a negative binomial defined in [6],

$$
\operatorname{Pr}(Y=y \mid \mu, \alpha)=\frac{\Gamma\left(y+\alpha^{-1}\right)}{\Gamma(y+1) \Gamma\left(\alpha^{-1}\right)}\left(\frac{\alpha^{-1}}{\alpha^{-1}+\mu}\right)^{\alpha^{-1}}\left(\frac{\mu}{\alpha^{-1}+\mu}\right)
$$

where $\boldsymbol{y}$ is the count for our dependent variable, $\mu=\exp (\boldsymbol{x} \beta), \alpha \geq 0$ is the overdispersion parameter, $\Gamma($.$) is the$ gamma function, and $\boldsymbol{x}$ is a vector of regressors. This specification assumes constant dispersion within groups, equal to $1+\alpha \mu$. The mean and variance of $\boldsymbol{y}$ are defined as $\mu$ and $\mu+\alpha \mu^{2}$, respectively. 
The log-likelihood function for exponential mean $\mu_{i}=\exp \left(\boldsymbol{x}_{\boldsymbol{i}}^{\prime} \beta\right)$ is therefore

$$
\ln L(\alpha, \beta)=\sum_{i=1}^{n}\left(\left(\sum_{j=0}^{y-1} \ln \left(j+\alpha^{-1}\right)\right)\right)-\ln y_{i} !-\left(y_{i}+\alpha^{-1}\right) \ln \left(1+\alpha \exp \left(x_{\boldsymbol{i}}^{\prime} \beta\right)\right)+y_{i} \ln \alpha+y_{i} x_{\boldsymbol{i}}^{\prime} \beta
$$

The vector of regressors constituted by the number of vacancies available in each program in the first phase of the national competition (Vacancies), classification of the last allocated student (Classification), program size (Degree), and IHE type (IHE), as a dummy variable.

The results of the negative binomial regression on the total of allocated student in each program for the regressors considered are presented in Table 3.

As for the pre-Bologna period, the variable Degree is not statistically significant then we repeated the process without it. Table 4 presents the results for this model.

\begin{tabular}{|c|c|c|c|}
\hline Year & & $\begin{array}{l}\text { First cycle } \\
\text { licenciatura) }\end{array}$ & $\begin{array}{l}\text { Integrated master } \\
\text { mestrado integrado) }\end{array}$ \\
\hline \multirow[t]{2}{*}{2007} & PI & 129 & 0 \\
\hline & $\mathrm{U}$ & 57 & 47 \\
\hline \multirow[t]{2}{*}{2008} & PI & 144 & 0 \\
\hline & $\mathrm{U}$ & 61 & 47 \\
\hline \multirow[t]{2}{*}{2009} & PI & 148 & 0 \\
\hline & $\mathrm{U}$ & 57 & 55 \\
\hline \multirow[t]{2}{*}{2010} & PI & 156 & 0 \\
\hline & $\mathrm{U}$ & 58 & 57 \\
\hline \multirow[t]{2}{*}{2011} & PI & 154 & 0 \\
\hline & $\mathrm{U}$ & 540 & 60 \\
\hline \multirow[t]{2}{*}{2012} & PI & 147 & 0 \\
\hline & $\mathrm{U}$ & 53 & 63 \\
\hline \multirow[t]{2}{*}{2013} & PI & 113 & 0 \\
\hline & $\mathrm{U}$ & 49 & 64 \\
\hline \multirow[t]{2}{*}{2014} & PI & 104 & 0 \\
\hline & $\mathrm{U}$ & 47 & 65 \\
\hline \multirow[t]{2}{*}{2015} & PI & 100 & 0 \\
\hline & $\mathrm{U}$ & 45 & 64 \\
\hline
\end{tabular}

\begin{tabular}{|c|c|c|c|}
\hline & \multicolumn{3}{|c|}{$\begin{array}{l}\text { TABLE 2. Description of the variables used in the } \\
\text { model }\end{array}$} \\
\hline Year & $\begin{array}{l}\text { Number of } \\
\text { Academic } \\
\text { Programs } \\
\end{array}$ & $\begin{array}{l}\text { Number of } \\
\text { Vacancies }\end{array}$ & $\begin{array}{c}\text { Number of } \\
\text { Allocated } \\
\text { Students } \\
\end{array}$ \\
\hline 2007 & 233 & 11603 & 9161 \\
\hline 2008 & 252 & 12203 & 10650 \\
\hline 2009 & 260 & 12580 & 10336 \\
\hline 2010 & 271 & 13026 & 9869 \\
\hline 2011 & 26 & 12846 & 8859 \\
\hline 2012 & 263 & 12611 & 7371 \\
\hline 2013 & 226 & 11701 & 6356 \\
\hline 2014 & 216 & 11340 & 5852 \\
\hline 2015 & 209 & 10962 & 7755 \\
\hline
\end{tabular}

FIGURE 2. Variation of the classification of the last allocated student by type of IHE

TABLE 3. Parameters Estimates for Students Allocation, Negative Binomial Model.

\begin{tabular}{ccccccc}
\hline & & & \multicolumn{2}{c}{$\begin{array}{c}\text { H5\% Wald Confidence } \\
\text { Interval }\end{array}$} & \multicolumn{2}{c}{ Hypothesis Test } \\
\hline Parameter & $\boldsymbol{\beta}$ & Std. Error & Lower & Upper & $\begin{array}{c}\text { Wald Chi- } \\
\text { Square }\end{array}$ & p-value \\
\hline Intercept & .996 & .1365 & .728 & 1.263 & 53.216 & $<.0001$ \\
Vacancies & .018 & .0002 & .017 & .018 & 7785.271 & $<.0001$ \\
Classification & .010 & .0018 & .007 & .014 & 33.789 & $<.0001$ \\
IHE & .363 & .0662 & .234 & .493 & 30.149 & $<.0001$ \\
\hline Degree & -.019 & .0249 & -.068 & .030 & .601 & .438 \\
\hline
\end{tabular}


TABLE 4. Parameters Estimates for Students Allocation, Negative Binomial Model, without the variable Degree

\begin{tabular}{ccccccc}
\hline & & \multicolumn{2}{c}{$\begin{array}{c}\text { 95\% Wald Confidence } \\
\text { Interval }\end{array}$} & \multicolumn{2}{c}{ Hypothesis Test } \\
\hline Parameter & $\boldsymbol{\beta}$ & Std. Error & Lower & Upper & $\begin{array}{c}\text { Wald Chi- } \\
\text { Square }\end{array}$ & $\begin{array}{c}\text { p-value } \\
\text { Intercept }\end{array}$ \\
Vacancies & 1.014 & .1274 & .765 & 1.264 & 63.365 & $<.0001$ \\
Classification & .018 & .0002 & .017 & .018 & 5513.543 & $<.0001$ \\
IHE & .010 & .0015 & .007 & .013 & 43.548 & $<.0001$ \\
\hline
\end{tabular}

\section{FINAL REMARKS}

The results obtained confirm that the model applied to the Pre-Bologna period data also explains the number of allocated students during the Post-Bologna period. It seems that the conditions are fulfilled for analyze the behavior of this model for all data (1997-2015) and conduct the comparison between the two periods in order to assess the impact of bologna on the student allocation in academic engineering programs in Portugal.

\section{ACKNOWLEDGMENTS}

A. Manuela Gonçalves and Raquel Oliveira were supported by the Research Centre of Mathematics of the University of Minho with the Portuguese Funds from the "FCT-Fundação para a Ciência e a Tecnologia", through the Project PEstOE/MAT/UI0013/2014. This research was financed by Portuguese.

Rosa M. Vasconcelos was supported by the Foundation through FCT - Fundação para a Ciência e Tecnologia, within the Project UID/MAT/00013/2013, by FEDER funds through the Competitivity Factors Operational Programme - COMPET and by national funds through FCT within the scope of the project POCI-01-0145-FEDER007136.

\section{REFERENCES}

1. Raquel Oliveira, A. Manuela Gonçalves and Rosa M. Vasconcelos, "A negative binomial model for student allocation to higher education in Portugal during the pre-Bologna period," in $11^{\text {th }}$ International Conference of Numerical Analysis and Applied Mathematics-2013, AIP Conference Proceedings1558, pp. 1881-1884.

2. http://www.dges.mctes.pt/DGES/pt/Estudantes/Acesso.

3. R. Oliveira, A. Manuela Gonçalves and Rosa M. Vasconcelos, "A Statistical Model for the Demand of Undergraduate Engineering Courses in Portugal: A First Study of Bologna Process Impact", in 10 $0^{\text {th }}$ International Conference of Numerical Analysis and Applied Mathematics-2012, AIP Conference Proceedings 1479, pp.17241727.

4. A.R. Cardoso, M. Portela, C. Sá and F. Alexandre, "Demand for higher education programs: the impact of the Bologna Process", CESifo Economic Studies, 54 2, 229-247, 2008.

5. M. Portela, C. Sá, F. Alexandre and A.R. Cardoso, "Perceptions of the Bologna process: what do students' choices reveal?", High Educ 58:465-474, 2009.

6. A.C. Cameron and P.K. Trivedi, "Regression Analysis of Count Data", Cambridge: Cambridge University Press, 1998. 